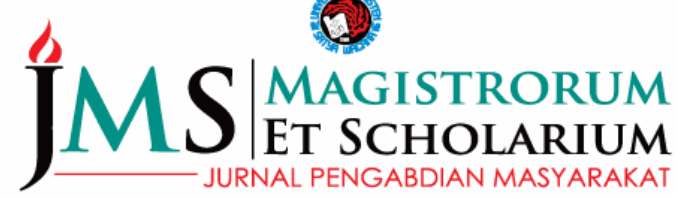

P-ISSN: 2722-9270 ejournal.uksw.edu/jms

\section{Peningkatan Literasi Keuangan pada UMKM melalui Pelatihan dan Pendampingan Pembukuan Sederhana}

\author{
Natasia Alinsari* \\ Fakultas Ekonomika dan Bisnis, Universitas Kristen Satya Wacana
}

A R T I C L E I N F O

Article history:

Received 08-01-2021

Revised 11-01-2021

Accepted 20-01-2021

Key words:

UMKM, Pembukuan Sederhana

\begin{abstract}
A B S T R A C T
UMKM are expected to be at the forefront of strengthening the economic pillars in achieving the Sustainable Development Goals (SGDs). This is because UMKM are one of the businesses that are most able to survive in a deteriorating economic condition, especially in the conditions of the Covid-19 pandemic. Therefore, UMKM must have good financial management so that the business can be sustainable. One of them is by having correct financial records and being able to compile the financial reports needed to make decisions in planning the next business strategy. UMKM Batik in Tegalrejo Village, Gedangsari, does not have good records so they are unable to produce financial reports. The results of training and assistance in making simple bookkeeping and compiling financial reports increase the awareness of UMKM of the importance of information generated by financial reports as a basis for decision making and formulating business strategies to achieve sustainable business.
\end{abstract}

\begin{abstract}
A B S T R A K
UMKM diharapkan menjadi garda terdepan untuk memperkuat pilar ekonomi dalam mencapai tujuan pembangunan berkelanjutan atau Sustainable Development Goals (SGDs). Hal ini dikarenakan UMKM menjadi salah satu usaha yang paling mampu bertahan dalam kondisi perekonomian yang memburuk terutama dalam kondisi pandemi Covid-19 ini. Oleh karena itulah, UMKM harus memiliki pengelolaan keuangan yang baik supaya usaha yang dijalankan dapat berkelanjutan. Salah satunya dengan memiliki pencatatan keuangan yang benar serta mampu menyusun laporan keuangan yang diperlukan untuk mengambil keputusan dalam merencanakan strategi bisnis yang selanjutnya. UMKM Batik di Desa Tegalrejo Kecamatan Gedangsari belum memiliki pencatatan yang baik sehingga tidak mampu menghasilkan laporan keuangan. Hasil pelatihan dan pendampingan membuat pembukuan sederhana dan menyusun laporan keuangan ini meningkatkan kesadaran pelaku UMKM akan pentingnya informasi yang
\end{abstract}

\footnotetext{
*Corresponding author: natasia.alinsari@uksw.edu
} 


\section{PENDAHULUAN}

Pandemi Covid-19 yang melanda dunia, khususnya Indonesia sangat berdampak signifikan khususnya dalam hal pertumbuhan ekonomi, salah satunya dirasakan oleh Usaha Kecil Mikro Menengah (UMKM). Berdasarkan survei terhadap 202 pelaku usaha kuliner seperti usaha roti, biskuit, cake, jajanan pasar, pancake dan pastry di Surabaya dan Jakarta, sekitar 94\% UMKM terdampak Covid-19 (Laoli, 2020). Menghadapi kondisi tersebut, pemerintah cukup menunjukkan dukungannya untuk terus mengajak UMKM bertahan, bahkan bergerak maju demi menopang perekonomian Indonesia. Salah satu dukungan yang diberikan pemerintah, terwujud melalui komitmen pemberian dana yang disiapkan untuk UMKM dalam program Pemulihan Ekonomi Nasional (PEN) sebesar Rp 123,46 triliun, yang sampai dengan 30 Juli 2020 sudah terserap sekitar 22,57\% atau sebesar Rp 27,86 triliun. UMKM diharapkan menjadi garda terdepan dalam pencapaian pilar perekonomian agenda pembangunan dunia di tahun 2030 sesuai dengan target tujuan pembangunan berkelanjutan atau Sustainable Development Goals (SGDs). Lebih lanjut harapan tersebut diwujudkan dalam bentuk penciptaan lapangan pekerjaan penciptaan kondisi kerja yang layak, inovasi bisnis, adaptasi dan mitigasi dampak negatif ekonomi, sosial dan lingkungan pada operasi bisnis untuk pertumbuhan ekonomi yang inklusif serta berkelanjutan (Siregar, 2020).

Beberapa contoh kondisi UMKM dapat mendorong perekonomian Indonesia adalah UMKM mampu menyerap tenaga kerja yang terbesar, 97\% dari total tenaga kerja di Indonesia berada di sektor UMKM. Sebagian besar masyarakat mengandalkan penghasilan sebagai pelaku usaha maupun pekerja di sektor UMKM (Fajar, 2020). Sementara itu, sebelum pandemi Covid-19 kontribusi UMKM di tahun 2019 telah mencapai 60,34\% terhadap PDB Nasional, terhadap nilai ekspor sebesar 14,17\%, dan $58,18 \%$ terhadap nilai investasi (Andilala, 2020).

Pandemi Covid-19 begitu berdampak bagi UMKM, namun ternyata masih ada harapan yang muncul dari beberapa di antaranya, seperti UMKM Batik yang terletak di Desa Tegalrejo, Kecamatan Gedangsari, Daerah Istimewa Yogyakarta yang meskipun terdampak pandemi namun tetap bertahan untuk menunjukkan eksistensinya. Kecamatan Gedangsari sendiri membawahi 10 desa, salah satunya Desa Tegalrejo yang menjadi tempat pengembangan Kampung Berseri Astra yang diresmikan sejak tahun 2018. Konsep Kampung Berseri Astra yang dibangun di Kecamatan Gedangsari merupakan konsep wisata edukasi dengan beberapa unit usaha di dalamnya, seperti usaha jamu, usaha batik, usaha keripik, usaha cobek, usaha kentongan dengan jumlah tenaga kerja saat ini berada di kisaran 3-5 orang per UMKM. Untuk unit usaha batik sendiri ada 10 UMKM yang sudah berdiri kurang lebih selama 10 tahun dan menjadi pemasok dari beberapa toko batik terkemuka di Daerah Istimewa Yogyakarta dan bahkan sampai di luar provinsi, seperti di Klaten, Solo dan Bali. UMKM batik di Desa Tegalrejo ini menjadi mitra binaan Yayasan Dharma Bhakti Astra yang bertujuan untuk mengembangkan perekonomian Indonesia melalui 
pengembangan bisnis UMKM melalui transfer ilmu dan pengetahuan dari pihak yang ditunjuk oleh Yayasan Dharma Bhakti Astra sebagai narasumber pelatihan dan pendampingan.

Kondisi 10 UMKM batik tersebut saat ini dalam keadaan stabil, meskipun pandemi cukup mempengaruhi, namun UMKM ini masih dapat terus berproduksi dan memasarkan produknya sampai ke luar provinsi. Selain produksi batik tulis dan cap, UMKM batik juga menjual jasa pewarnaan batik yang juga cukup banyak diminta oleh pasar. Meski demikian sudah selayaknya jika operasional dan pengembangan pasar UMKM didukung dengan pengelolaan keuangan yang baik, salah satunya dengan pencatatan keuangan yang ternyata sampai saat ini masih dilakukan seadanya. Pencatatan keuangan sangat diperlukan oleh suatu unit bisnis sebagai acuan dalam melihat kondisi bisnis yang tengah dijalankan (Rumi, 2020). Lebih lanjut, pentingnya pencatatan keuangan bagi UMKM adalah sebagai alat pengambilan keputusan. Hasil dari pencatatan keuangan berupa laporan keuangan sederhana dapat dipakai untuk mengambil keputusan untuk strategi bisnis selanjutnya. Setiap keuntungan atau kerugian yang dihasilkan oleh UMKM dapat dipakai oleh para pemangku kepentingan sebagai bahan pertimbangan untuk melakukan ekspansi pasar atau keputusan strategis lainnya (Ayunda, 2020).

UMKM batik di Desa Tegalrejo sejauh ini belum memiliki laporan keuangan yang bersifat baku dan sesuai dengan ketentuan yang berlaku umum. Pencatatan keuangan jarang sekali dilakukan, bahkan juga ada yang tidak melakukan sama sekali. Beberapa UMKM yang melakukan pencatatan keuangan juga sebatas pada arus kas penerimaan dan pengeluaran. Selain itu yang menjadi masalah terkait pencatatan keuangan yang dilakukan oleh UMKM batik ini adalah belum terpisahnya entitas bisnis dengan pribadi. Keseluruhan UMKM menyatakan bahwa masih terlalu sulit untuk mengidentifikasi aset pribadi dan usaha yang berdampak pada pencatatan keuangan yang pada akhirnya belum mampu menggambarkan kondisi usaha yang sebenarnya. Sementara itu, sebagai mitra binaan Yayasan Dharma Bhakti Astra, UMKM batik di Desa Tegalrejo ini diharapkan mampu membuat laporan keuangan sederhana yang menggambarkan kondisi riil usaha.

Tujuan dari kegiatan pengabdian kepada masyarakat ini adalah sebagai bentuk pelaksanaan tridharma perguruan tinggi untuk memberikan pelatihan kepada UMKM terkait pembukuan sederhana, termasuk di dalamnya cara membukukan dan manfaatnya bagi unit usaha. Selain itu, tujuan dari pengabdian kepada masyarakat ini juga merancang bentuk pembukuan sederhana yang paling mungkin dilakukan oleh UMKM, sekaligus mendampingi UMKM dalam mengimplementasikan pembukuan tersebut di dalam aktivitas bisnis sehari-hari. Adapun manfaat dari kegiatan ini adalah meningkatkan pemahaman pelaku usaha tentang manfaat dari melakukan pembukuan dan secara praktis dapat membukukan setiap transaksi keuangan yang terjadi, termasuk di dalamnya dapat melakukan pemisahan entitas bisnis usaha dan pribadi.

Menurut Undang-Undang Nomor 28 tahun 2007 tentang Ketentuan Umum dan Tata Cara Perpajakan (Peraturan Pemerintah Republik Indonesia, 2007), pembukuan sederhana merupakan suatu proses pencatatan yang dilakukan secara teratur dan berkala untuk mengumpulkan data dan informasi keuangan. Pencatatan keuangan ini meliputi harta, kewajiban, modal, penghasilan, dan biaya, serta jumlah harga perolehan dan penyerahan barang atau jasa. Berikutnya luaran yang dihasilkan dari 
pencatatan keuangan tersebut berupa laporan keuangan yang biasanya berupa neraca, laporan laba rugi, laporan arus kas dan laporan perubahan modal.

Asumsi dasar akuntansi perlu dipertimbangkan di dalam penyusunan laporan keuangan, tujuannya adalah agar laporan keuangan dapat disajikan secara akurat dan dapat dipertanggungjawabkan. Salah satu asumsi dasar akuntansi tersebut adalah asumsi kesatuan usaha. Konsep ini melihat sebuah organisasi sebagai suatu unit usaha yang berdiri sendiri, terpisah dari pemiliknya. Organisasi atau perusahaan dianggap sebagai unit akuntansi yang terpisah dari pemiliknya atau dari kesatuan usaha yang lain (Wadiyo, 2020). Dengan demikian untuk konsep kesatuan usaha maka semua transaksi yang ada di dalam perusahaan harus dipisah dengan transaksi pribadi pemilik perusahaan (Aanwijzing, 2019).

\section{METODE PELAKSANAAN}

Kegiatan pengabdian masyarakat di Desa Tegalrejo ini dilaksanakan pada bulan September - Oktober tahun 2020 bertempat di Balai Desa Tegalrejo dan di showroom UMKM batik. Kegiatan pengabdian masyarakat yang dilaksanakan ini meliputi pelatihan dan pendampingan pembukuan keuangan untuk dapat menghasilkan laporan keuangan sederhana unit usaha. Kegiatan pelatihan dan pendampingan pembukuan sederhana dilakukan dengan melalui tahapan seperti yang terlihat pada Tabel 1 .

Tabel 1. Jadwal Pelaksanaan Kegiatan

\begin{tabular}{|c|c|c|c|c|}
\hline No & Kegiatan & September 2020 & Oktober 2020 & Pelaksana \\
\hline 1 & $\begin{array}{l}\text { Survei Pendahuluan dan } \\
\text { Identifikasi Permasalahan }\end{array}$ & $\mathrm{V}$ & & $\begin{array}{c}\text { Tim Pengabdi dan } \\
\text { YDBA }\end{array}$ \\
\hline 2 & $\begin{array}{l}\text { Koordinasi dengan UMKM } \\
\text { batik Desa Tegalrejo dan } \\
\text { Pemerintah Desa Tegalrejo }\end{array}$ & V & & $\begin{array}{c}\text { Tim Pengabdi dan } \\
\text { YDBA }\end{array}$ \\
\hline 3 & $\begin{array}{l}\text { Pelatihan Pembukuan } \\
\text { Sederhana di Balai Desa } \\
\text { Tegalrejo }\end{array}$ & V & & $\begin{array}{c}\text { Tim Pengabdi dan } \\
\text { YDBA }\end{array}$ \\
\hline 4 & $\begin{array}{l}\text { Pendampingan Pembukuan } \\
\text { Sederhana UMKM batik Desa } \\
\text { Tegalrejo }\end{array}$ & & $\mathrm{V}$ & $\begin{array}{c}\text { Tim Pengabdi dan } \\
\text { YDBA }\end{array}$ \\
\hline 5 & $\begin{array}{l}\text { Penyusunan Laporan } \\
\text { Pengabdian Masyarakat }\end{array}$ & & $\mathrm{V}$ & Tim Pengabdi \\
\hline
\end{tabular}

Peserta pelatihan pembukuan sederhana ini adalah beberapa UMKM di Desa Tegalrejo yang terdiri dari UMKM batik, UMKM keripik, dan UMK kerajinan gerabah. Sementara itu, untuk peserta pendampingan difokuskan untuk UMKM batik saja. Secara lebih rinci, pelaksanaan pengabdian masyarakat ini dilakukan dalam beberapa langkah dengan metode sebagai berikut: (1) Survei pendahuluan dilakukan dalam rangka melihat kondisi UMKM di Desa Tegalrejo terutama di era pandemi Covid-19. Selain itu, juga dilakukan identifikasi terhadap masalah yang dihadapi sebagai bagan untuk perancangan materi pelatihan dan pendampingan di dalam kegiatan pengabdian masyarakat ini; (2) Koordinasi dengan Pemerintah Desa Tegalrejo dilakukan untuk memastikan tempat pelaksanaan kegiatan pengabdian masyarakat sekaligus juga memetakan permasalahan umum yang dihadapi oleh 
UMKM di Desa Tegalrejo khususnya terkait dengan pengelolaan keuangan, sedangkan koordinasi dengan UMKM batik juga dilakukan dalam rangka memastikan kebutuhan dari UMKM batik sesuai dengan materi pelatihan dan pendampingan yang nantinya akan disampaikan; (3) Pengumpulan acuan dan kajian pustaka terkait pembukuan sederhana bagi UMKM sebagai dasar pembuatan materi pelatihan dan pendampingan. Materi dibuat dalam bentuk presentasi lengkap dengan contoh kasus untuk memudahkan dalam mentransfer pengetahuan kepada UMKM; (4) Perancangan metode pembukuan sederhana dan pelatihan langsung serta pendampingan yang diberikan kepada UMKM di Desa Tegalrejo.

\section{HASIL DAN PEMBAHASAN}

Kegiatan pengabdian masyarakat ini dilaksanakan sesuai dengan rencana kegiatan. Pelatihan dilaksanakan pada pertengahan akhir September setelah di awal bulan, tim pengabdi bersama dengan YDBA melakukan survei pendahuluan untuk melihat kondisi UMKM di Desa Tegalrejo. Pelatihan dilaksanakan selama dua hari berturut-turut dengan menyampaikan materi terkait pembukuan sederhana, kemudian pada pertemuan berikutnya dilakukan pendampingan pembukuan sederhana langsung ke UMKM.

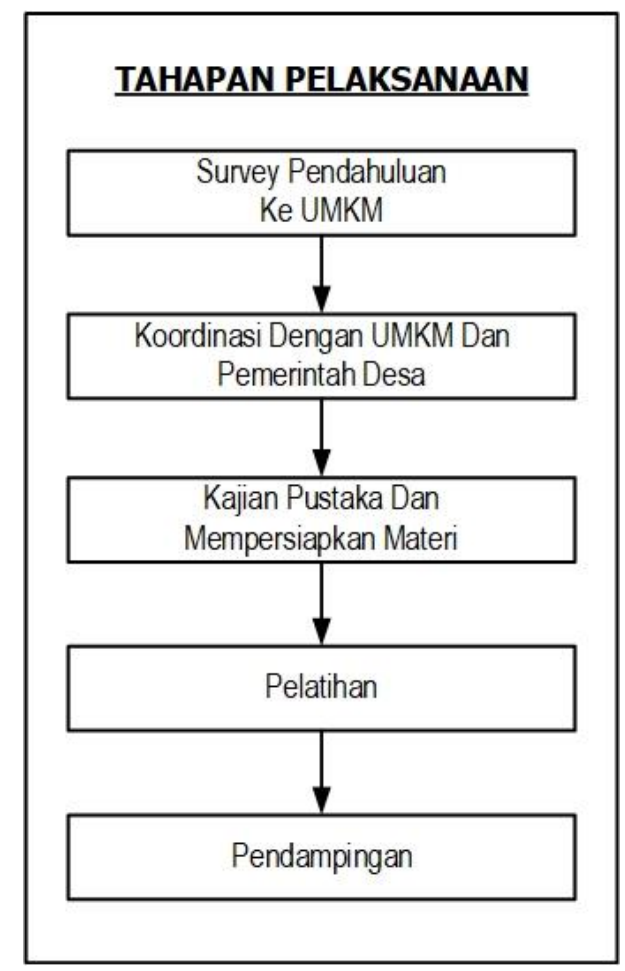

Gambar 1. Tahapan Pelaksanaan Pengabdian Masyarakat

Permasalahan utama yang dihadapi para UMKM adalah tidak adanya pemisahan antara keuangan rumah tangga dan usaha. Sebagian besar UMKM yang ada sejauh ini memang melakukan pencatatan tetapi hanya transaksi penjualan saja. Terkait dengan alokasi biaya usaha, masih tercampur dengan perhitungan buaya untuk keperluan 
rumah tangga. Demikian juga dengan penerimaan, transaksi kas masuk atas hasil usaha diakui menambah pemasukan rumah tangga. Pelaku UMKM cenderung menggunakan ingatan sebagai dasar pencatatan, transaksi yang dicatat dengan menggunakan dokumen pendukung tertulis yang lengkap masih sangat kurang. Sebagian besar UMKM hanya memiliki nota penjualan rangkap sebagai salah satu bentuk dokumen pendukung terkait dengan transaksi penjualan, namun untuk transaksi selain itu lebih banyak tanpa menggunakan dokumen pendukung. Selain itu, belum ada kebijakankebijakan akuntansi yang diterapkan di UKM, misalnya terkait saldo piutang yang menggantung, perhitungan metode persediaan dan pembebanan biaya ke produk. Secara umum permasalahan yang dialami oleh UMKM yang ada di Desa Tegalrejo ini lebih kepada kurangnya pengetahuan terkait kebijakan akuntansi dalam melakukan pembukuan sederhana dan mekanisme penentuan harga. Sebagian besar pelaku UMKM menentukan harga juga berdasarkan dengan kebiasaan dan harga pasaran. Penentuan biaya ke produk untuk menentukan harga jual cenderung diabaikan dan hanya berdasarkan intuisi saja. Selain permasalahan tersebut, para pelaku UMKM ini cenderung tidak memiliki waktu khusus untuk mengerjakan hal-hal yang bersifat administratif seperti membuat pembukuan sederhana. Kebanyakan dari UMKM ini memiliki pekerjaan lain di luar dari usaha yang dijalankan, ditambah dengan mereka melakukan semua aktivitas bisnis UMKM sendiri, sehingga tidak memiliki cukup waktu untuk tertib administrasi.

Pada hari pertama tim pengabdi memberikan pembekalan terkait pembukuan sederhana. Materi pembukuan sederhana ini meliputi mekanisme melakukan pencatatan atas setiap transaksi yang terjadi, mengelompokkan akun dan bukti transaksi serta menyusun laporan keuangan sederhana mulai dari menghitung laba atau rugi usaha, perubahan modal sampai pada pembuatan neraca. 


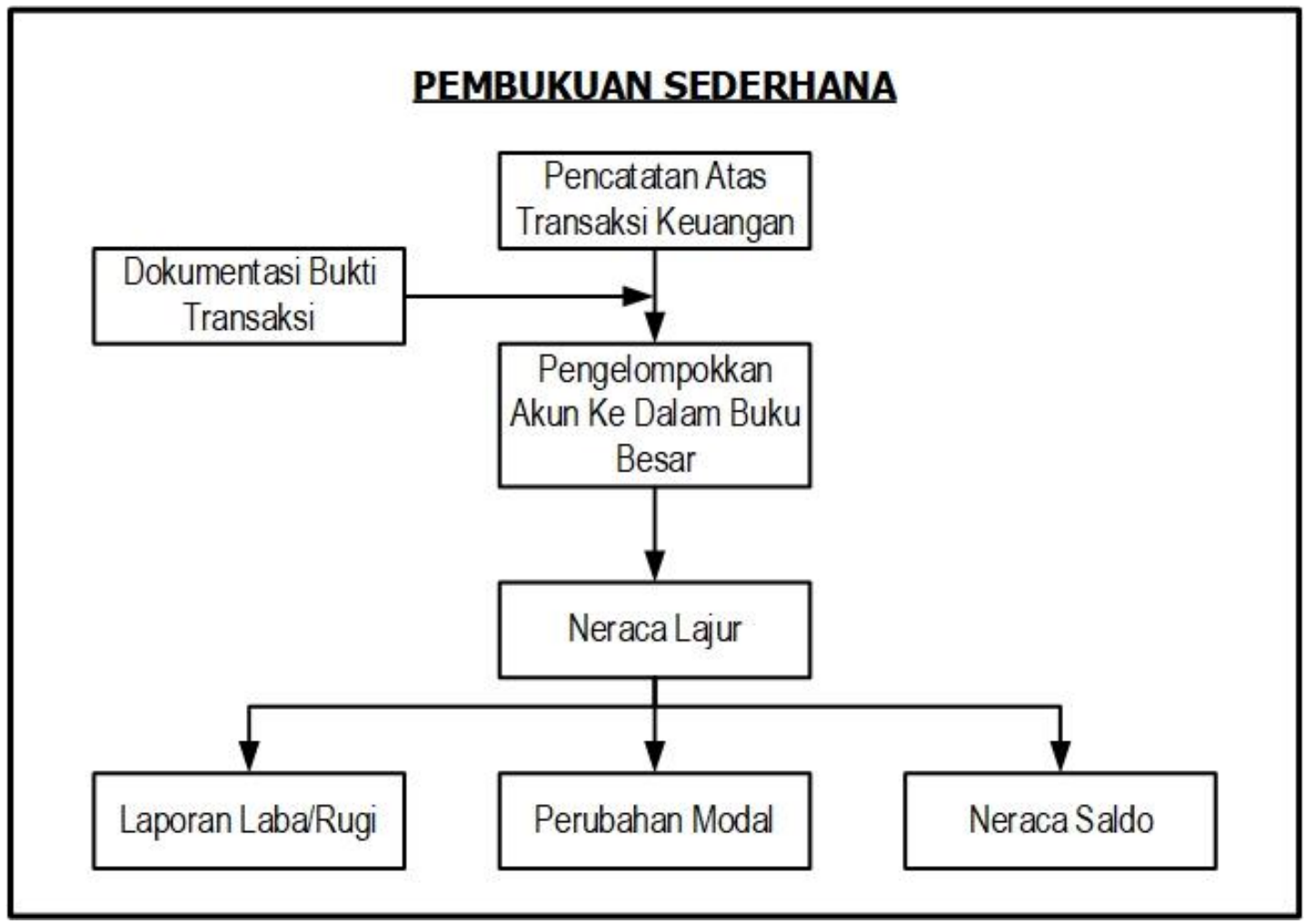

Gambar 2. Alur Pembukuan Sederhana

Pada pelatihan pembukuan sederhana ini, para pelaku UMKM tidak hanya menerima ulasan materi tetapi juga belajar mempraktikkan secara langsung tahapan pembukuan ini melalui contoh kasus. Pada akhir sesi hari pertama, tim pengabdi membuat simulasi untuk memberi gambaran nyata siklus akuntansi mulai dari pencatatan transaksi sampai pada penyusunan laporan keuangan. Pada hari kedua pelatihan, peserta diberi materi menghitung harga pokok produk. Sesi ini tidak kalah penting untuk disampaikan karena sebagian besar UMKM belum benar-benar memahami cara membebankan biaya ke produk. Biaya-biaya yang diperhitungkan biasanya hanya biaya utama, yaitu bahan baku dan tenaga kerja saja. Biaya overhead langsung, biaya overhead tidak langsung serta biaya periodik tidak diperhitungkan sebagai biaya produk. Pada sesi hari kedua ini, peserta pelatihan diminta mengidentifikasi biaya-biaya yang dikeluarkan dalam proses bahan mentah sampai bahan jadi diterima oleh pelanggan. 


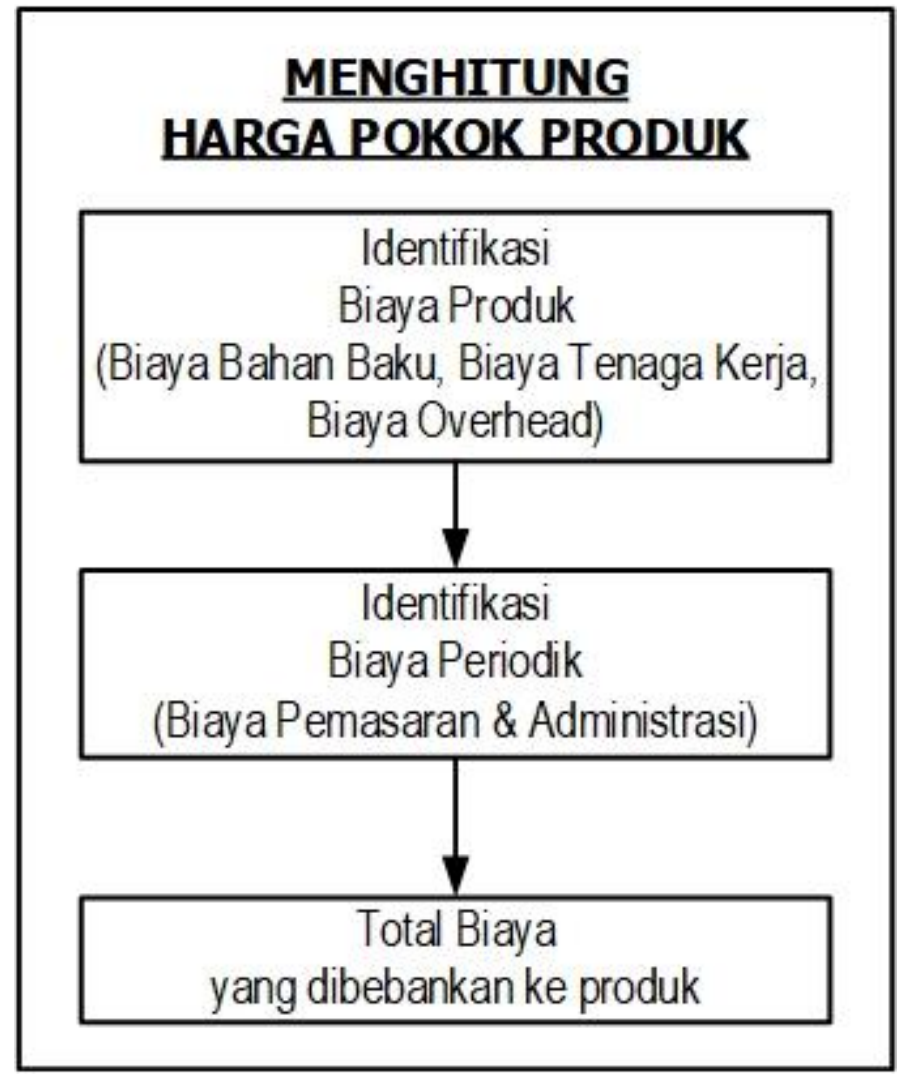

Gambar 3. Alur Menghitung Biaya Pokok Produk

Selain pelatihan, tim pengabdi juga melakukan pendampingan langsung kepada para pelaku UMKM sebagai tindak lanjut untuk membantu para pelaku UMKM dalam menghasilkan laporan keuangan sederhana sampai dengan menghitung pembebanan biaya ke produk. Pendampingan dilakukan selama tiga kali. Pada pendampingan pertama, tim pengabdi mendampingi para pelaku UMKM dalam mengidentifikasi aset, hutang dan modal usaha yang dimiliki untuk melihat posisi neraca tiap UMKM. Beberapa UMKM mampu mengidentifikasi saldo awal akun neraca, tetapi beberapa mengalami kesulitan. Hal ini terjadi karena memang tidak ada pemisahan keuangan antara rumah tangga dengan usaha. Pada pendampingan yang kedua, UMKM belajar mencatat transaksi yang terjadi dan mengelompokkan sesuai dengan akunnya. Sebenarnya, transaksi yang terjadi di dalam aktivitas bisnis UMKM tidak terlalu banyak jenisnya. Sebagian besar UMKM, dalam sepekan hanya memiliki transaksi penjualan saja. YDBA bersama dengan tim pengabdi menyediakan buku pencatatan keuangan untuk membantu UMKM melakukan pencatatan atas setiap transaksi yang terjadi dan dapat dengan mudah mengelompokkan pada tiap akun. Pencatatan transaksi ini terus dilanjutkan sampai pada pendampingan ketiga. Pada pendampingan ketiga, tim pengabdi memeriksa pencatatan transaksi yang dilakukan para UMKM. Kesalahan yang sering terjadi adalah pencatatan hanya dilakukan pada satu sisi saja. Sebagai contoh pencatatan atas transaksi penjualan secara tunai, hanya akun kas saja yang dicatat bertambah tetapi pada akun penjualan tidak ditambahkan dan sebaliknya. Berdasarkan transaksi yang terjadi selama dua pekan, tim pengabdi mendampingi para 
pelaku UMKM menyusun laporan keuangan sederhana yang dimulai dari laporan laba/ rugi, perubahan modal dan neraca saldo. Pada akhir rangkaian pelatihan dan pendampingan, masing-masing UMKM mempresentasikan hasil pembukuan sederhana yang disusun.

Berdasarkan hasil presentasi, secara umum, UMKM sudah mampu membuat laporan keuangan sederhana sendiri. UMKM sudah memahami alur dari mulai penentuan saldo awal di laporan keuangan, identifikasi atas transaksi serta pencatatannya di buku kas dan neraca lajur. Kendala di dalam pembuatan laporan keuangan sederhana yang dilakukan oleh UKM ini antara lain, keterbatasan sumber daya manusia. Sebagian besar pengelola UMKM berusia paruh baya dengan latar belakang pendidikan relatif rendah, serta banyaknya yang memiliki fungsi ganda yaitu sebagai pemilik UMKM sekaligus ibu rumah tangga. Hal ini menyebabkan terbatasnya waktu untuk melakukan pembukuan sekaligus berpotensi menyebabkan keuangan usaha dan rumah tangga tercampur. Selain itu, ditemukan pada saat pendampingan, keterbukaan UMKM relatif masih rendah. Kebanyakan dari para pelaku UMKM enggan memberikan data yang sesungguhnya dengan berbagai macam alasan, antara lain tidak ingin diketahui omzet per bulannya karena demi menyembunyikan kewajiban pajak, tidak bersedia menyampaikan data piutang karena tidak ingin pelanggan yang dimiliki diketahui oleh UMKM sejenis, terutama pelangganpelanggan besar.

\section{SIMPULAN}

Simpulan yang dapat diberikan dari kegiatan pengabdian masyarakat berupa pelatihan dan pendampingan pembukuan sederhana bagi UMKM Batik di Desa Tegalrejo ini adalah bahwa kegiatan tersebut dapat dilaksanakan dengan baik. Pelatihan dilakukan selama 2 hari, sementara pendampingan dilakukan selama 3 kali dengan jangka waktu tertentu. Hasil pelatihan dan pendampingan memberikan peningkatan literasi keuangan UMKM melalui pembuatan laporan keuangan sederhana dan melalui mekanime pembebanan biaya ke produk. Pelaku UMKM pada akhirnya memiliki pemahaman bahwa laporan keuangan dapat mencerminkan kondisi riil suatu usaha, secara lebih jauh laporan keuangan dapat dipakai sebagai sarana pengambilan keputusan bisnis. Terlihat bahwa kegiatan pengabdian masyarakat ini meningkatkan kesadaran pelaku UMKM bahwa penting untuk mampu memisahkan antara keuangan pribadi dan keuangan usaha. Meski demikian, kendala terkait sumber daya manusia yang merangkap di semua fungsi dalam aktivitas bisnis UMKM membuat ketidakmampuan dalam melakukan pembukuan usaha, di samping juga terkait latar belakang pendidikan dari masing-masing pelaku UMKM yang berbeda membuat adanya perbedaan di dalam memahami dan mengimplementasikan pembukuan sederhana yang diberikan. Dukungan dari YDBA juga perlu menjadi pertimbangan bagi pelaku UMKM untuk terus dapat memberikan literasi pengetahuan terkait keuangan dan akuntansi, misalnya dengan memberikan pelatihan dan pendampingan secara berkelanjutan. Selain itu perlu adanya penilaian terkait kinerja UMKM terkait pembuatan laporan keuangan oleh UMKM mitra dari YDBA. 


\section{DAFTAR PUSTAKA}

Aanwijzing, A. (2019). Asumsi dan konsep dasar akuntansi. Aanwijzing.Com. https://www.aanwijzing.com/2019/01/asumsi-dan-konsep-dasar-akuntansi.html

Andilala, A. (2020). Upaya pemerintah memaksimalkan peran UMKM di masa pandemi COVID-19. Kalbar.Antaranews.Com. https://kalbar.antaranews.com/berita/435942/upaya-pemerintahmemaksimalkan-peran-umkm-di-masa-pandemi-covid-19\#

Ayunda, A. (2020). 10 Alasan betapa pentingnya pembukuan bagi UMKM di Indonesia. Accurate.Id. https://accurate.id/akuntansi/pentingnya-pembukuanbagi-umkm-di-indonesia/

Fajar, T. (2020). Bukti UMKM memainkan peran penting bagi ekonomi RI.

Okezone.Com.

https://economy.okezone.com/read/2020/10/09/455/2291177/bukti-umkmmemainkan-peran-penting-bagi-ekonomi-ri

Laoli, N. (2020). UMKM memiliki peran strategis menopang kebangkitan ekonomi di tengah pandemi Covid-19. Kontan.Co.Id.

https://nasional.kontan.co.id/news/umkm-memiliki-peran-strategis-menopangkebangkitan-ekonomi-di-tengah-pandemi-covid-19

Peraturan Pemerintah Republik Indonesia. (2007). Undang-Undang Republik Indonesia Nomor 28 Tahun 2007. 


\section{LAMPIRAN}
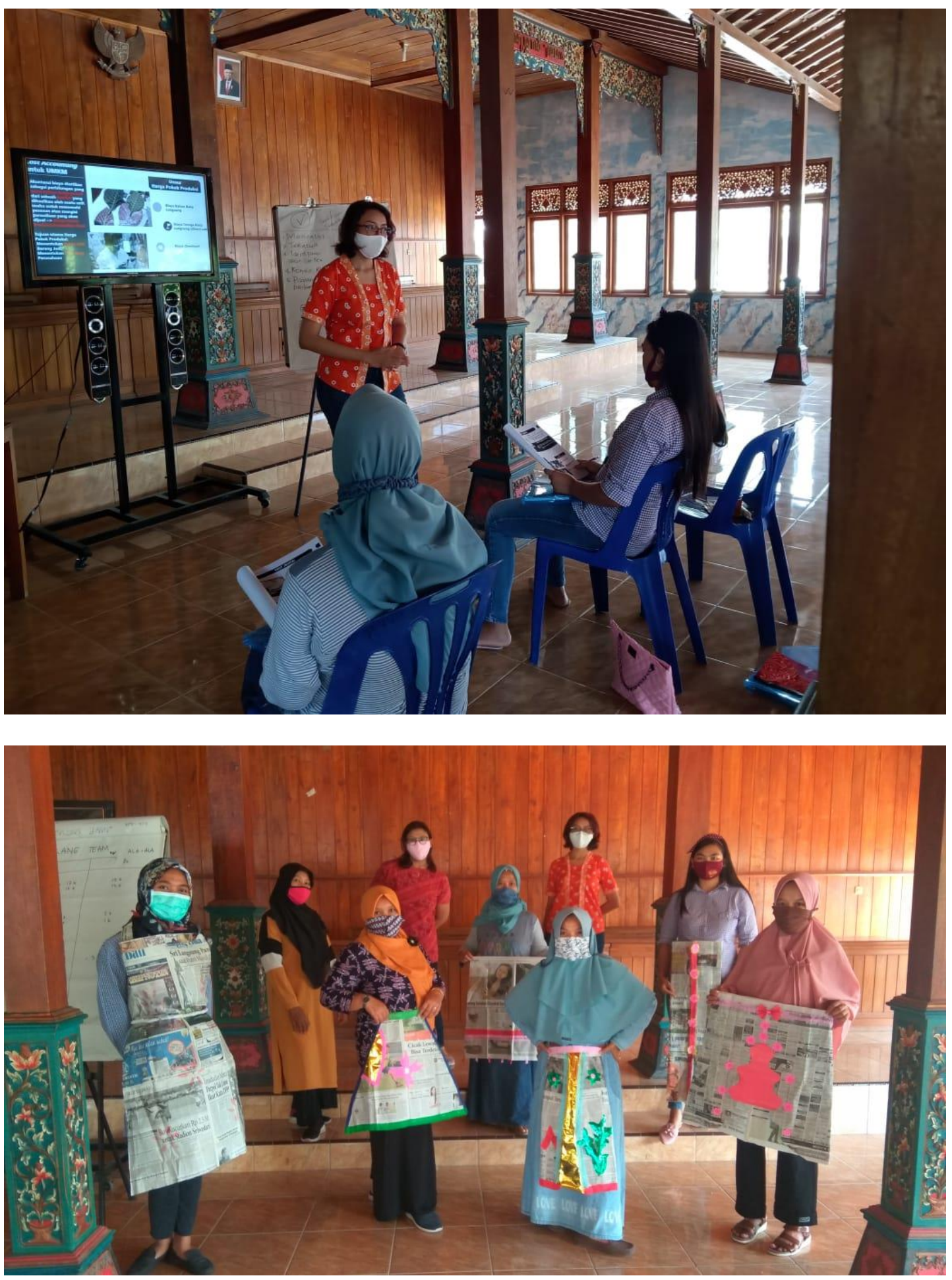

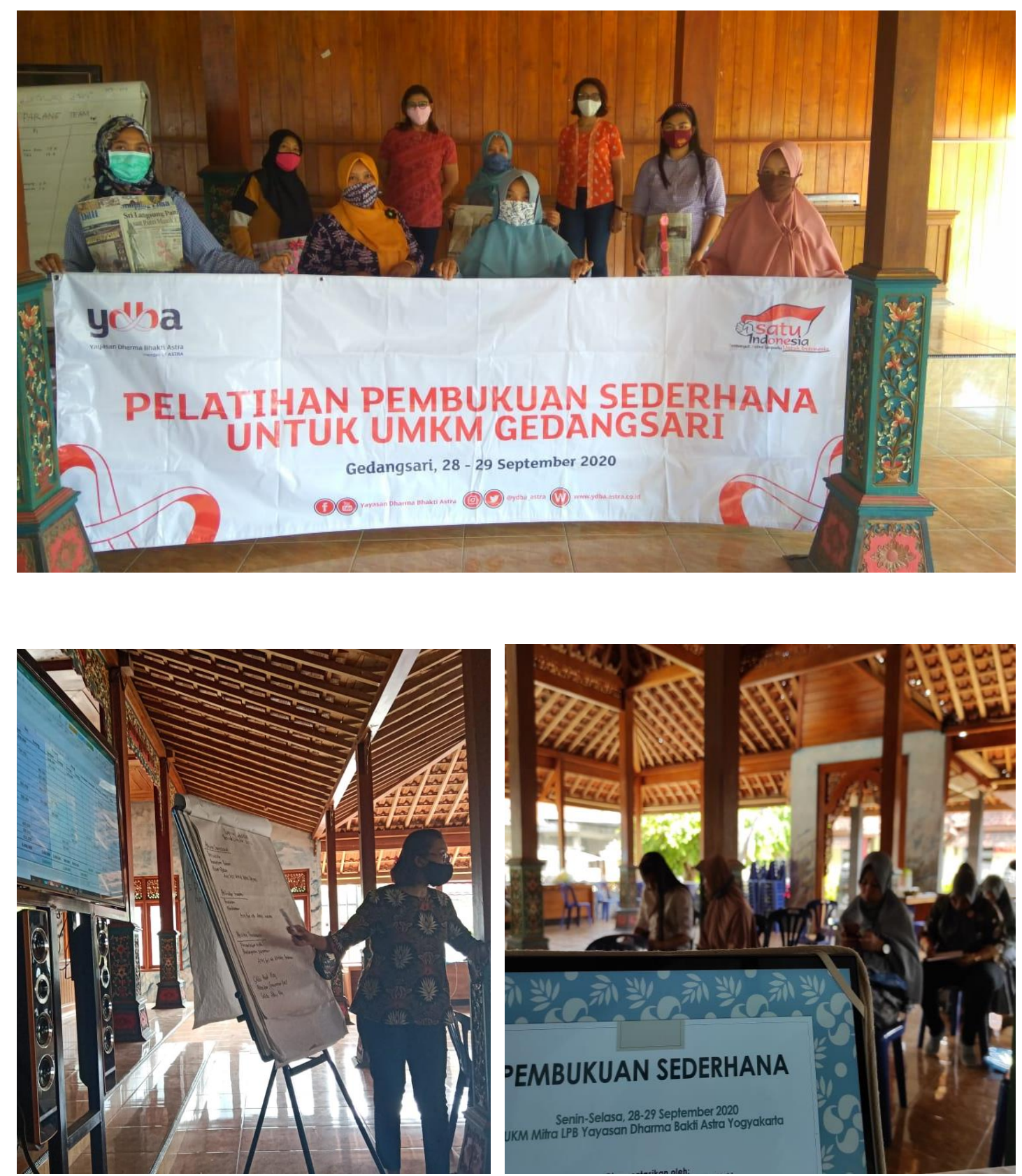


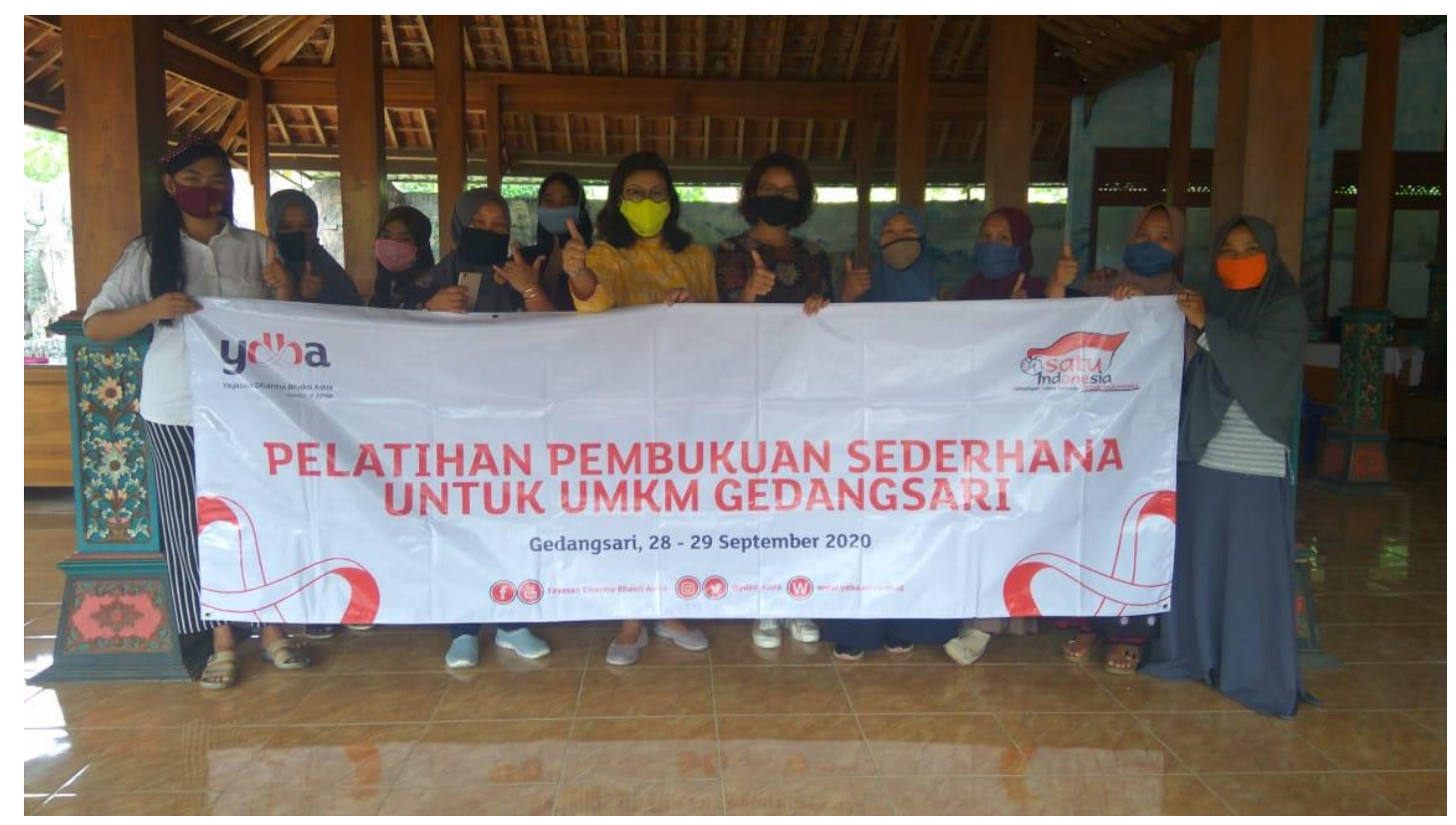

